\title{
Thin Film Iron Pyrite Deposited by Hybrid Sputtering/Co-Evaporation as a Hole Transport Layer for Sputtered CdS/CdTe Solar Cells
}

\author{
Khagendra P. Bhandari, Xinxuan Tan, Peymon Zereshki, Fadhil K. Alfadhili, \\ Adam B. Phillips, Prakash Koirala, Michael J. Heben, Robert W. Collins*, \\ and Randy J. Ellingson*
}

Wright Center for Photovoltaics Innovation and Commercialization, Department of Physics and Astronomy, School of Solar and Advanced Renewable Energy, The University of Toledo, 2801 West Bancroft Street, Toledo, OH 43606

\begin{abstract}
We report the properties of hybrid deposited iron pyrite $\left(\mathrm{FeS}_{2}\right)$ thin films applied as the back contact interface layers of $\mathrm{CdS} / \mathrm{CdTe}$ solar cells. The hybrid deposition process for $\mathrm{FeS}_{2}$ optimized in this study relies on DC magnetron sputtering of iron with simultaneous thermal evaporation of sulfur. We have fabricated solar cells incorporating CdS/CdTe window/absorber layers sputter-deposited onto commercial transparent conducting oxide coated glass and have compared the performance of devices incorporating the new $\mathrm{FeS}_{2} / \mathrm{Cu} / \mathrm{Au}$ back contacts with that of standard devices incorporating $\mathrm{Cu} / \mathrm{Au}$ back contacts. Considering our best devices of each type, the inclusion of the $\mathrm{FeS}_{2}$ thin film as a hole transport layer has improved the open circuit voltage $\mathrm{V}_{\mathrm{OC}}$ by $2.1 \%$, reaching $817 \mathrm{mV}$, and the fill-factor $\mathrm{FF}$ by $8.3 \%$ relative, reaching $74.7 \%$, in comparison with devices omitting the $\mathrm{FeS}_{2}$ layer. Under standard test conditions of 100 $\mathrm{mA} / \mathrm{cm}^{2}$ simulated $\mathrm{AM} 1.5 \mathrm{G}$ and $25{ }^{\circ} \mathrm{C}$, devices utilizing the $\mathrm{FeS}_{2}$ hole transport layer have shown a conversion efficiency $\eta$ as high as $13.3 \%$-- a relative increase in $\eta$ of $\sim 10 \%$ over our current laboratory standard back contact. The attained FF exceeds previous results for high efficiency sputter-deposited CdS/CdTe solar cells.
\end{abstract}

\section{KEYWORDS}

Iron pyrite, CdTe, solar cells, hybrid sputtering/evaporation, back contact, hole transport layer

\section{*Correspondence}

Randy Ellingson and Robert Collins, Department of Physics and Astronomy, University of Toledo, Research and Technology Complex 1, MS 218, 2600 Dorr Street, Toledo, OH 43615, USA

Email: randy.ellingson@utoledo.edu; robert.collins@utoledo.edu 


\section{INTRODUCTION}

Iron pyrite $\left(\mathrm{FeS}_{2}\right)$ is an earth-abundant, low cost, and low-toxicity sulfur mineral and has been identified as a promising candidate thin film material for large-scale deployment of solarto-electricity generation $[1,2] . \mathrm{FeS}_{2}$ exhibits an indirect bandgap of $\sim 0.95 \mathrm{eV}$, but also displays desirable high optical absorption starting in the near infra-red near $\sim 1 \mathrm{eV}$ and extending into the visible spectral range, thus enabling relatively thin absorber layers that serve to minimize materials cost [2-5]. Although iron pyrite has been extensively researched for photovoltaic (PV) applications since the mid-1980s [2], the record conversion efficiency of just $2.8 \%$ shows that $\mathrm{FeS}_{2}$ has not been implemented successfully as an absorber for high efficiency PV cells [2, 6-8]. We recently discovered, however, that certain properties shared by most polycrystalline and nanocrystalline (NC) $\mathrm{FeS}_{2}$ pyrite thin films, including a high free hole $(\mathrm{p}+)$ density and a relatively deep work function $(\approx 5.0 \mathrm{eV})$, support its application as a low-resistance hole transport layer (HTL) at the back contact of CdS/CdTe solar cells. Previously, we reported the use of a solution processed $\mathrm{FeS}_{2}$ thin film, based on colloidal $\mathrm{FeS}_{2} \mathrm{NCs}$, at the back contact to CdTe [9]. The deposited NC film, which was chemically modified using hydrazine to improve conductivity, yielded a relative improvement in solar conversion efficiency of $>5 \%$ when compared with test cells using our laboratory standard $\mathrm{Cu} / \mathrm{Au}$ back contact. We briefly review here additional properties of the NC-based $\mathrm{FeS}_{2}$ back contact layers before introducing the hybrid sputter/co-evaporation method utilized for deposition of the back contact layer of $\mathrm{CdS} / \mathrm{CdTe}$ solar cells as described in this manuscript.

The cubic $\mathrm{FeS}_{2}$ NCs utilized in the solution-process back contact have an average edge length of $\sim 100 \mathrm{~nm}$, and thin films prepared with that material are porous [10,11], with a void fraction of $\sim 0.5$ as determined by spectroscopic ellipsometry (SE) [11]. As a result, an $\mathrm{FeS}_{2} \mathrm{NC}$ film of at least $1 \mu \mathrm{m}$ thickness is required to minimize the adverse effect of film porosity when applying $\mathrm{FeS}_{2} \mathrm{NCs}$ as a back contact layer and to enhance the performance of the solar cells [9, 12]. When preparing the $\mathrm{FeS}_{2} \mathrm{NC}$ film, a hydrazine treatment enhances film conductivity by removing surfactant molecules present during and after NC synthesis. Despite potential advantages in terms of simplicity and cost, solution-based fabrication of thin films may not prove to be economically viable for large scale production. In addition, the use of hydrazine is clearly undesirable based on volatility and toxicity concerns.

Motivated by these issues, we report here for the first time the development and demonstration of a hybrid vacuum deposition method for preparing polycrystalline iron pyrite thin films on CdTe absorber layer surfaces. While many methods have been published for producing iron pyrite thin films, ours represents one that allows for low substrate temperatures while yielding high pyrite phase purity. This method relies on sputtering iron and concurrently evaporating sulfur to form an iron pyrite back contact on a $\mathrm{CdCl}_{2}$-activated $\mathrm{CdS} / \mathrm{CdTe}$ film stack held at elevated temperatures, but at least $\sim 50^{\circ} \mathrm{C}$ below the activation temperature. Our investigations have revealed favorable initial results, with $\mathrm{CdS} / \mathrm{CdTe} / \mathrm{FeS}{ }_{2}$ devices showing 
improvements in the open circuit voltage $\left(\mathrm{V}_{\mathrm{OC}}\right)$, fill-factor $(\mathrm{FF})$, and power conversion efficiency ( $\eta$ ) under AM1.5G simulated solar illumination. The efficiency of our highest performance device $(\eta=13.3 \%)$ prepared on a commercial transparent conducting oxide coated glass using the iron pyrite HTL compares well with the previously reported record efficiency of $14.0 \%$ for an all-sputtered CdS/CdTe thin film solar cell prepared on optimized $\mathrm{ZnO}: \mathrm{Al}$ [13] In fact, the FF for the highest efficiency cell using the iron pyrite HTL reported here exceeds that reported for the best cells in Ref. [13].

\section{EXPERIMENTAL DETAILS}

The cadmium sulfide $(\mathrm{CdS})$ window and CdTe absorber layers of all solar cells were deposited by RF magnetron sputtering onto $\mathrm{TEC}^{\mathrm{TM}} 15$ soda lime glass substrates coated with a $100 \mathrm{~nm}$ thick high resistivity transparent layer (HRT; Pilkington N. A.) [14]. The thicknesses of CdS and CdTe films were $\sim 80 \mathrm{~nm}$ and $\sim 2 \mu \mathrm{m}$, respectively. For characterization purposes, polycrystalline iron pyrite $\left(\mathrm{FeS}_{2}\right)$ films were prepared on uncoated soda lime glass and on silicon wafer substrates. In addition to these latter substrates, (TEC $\left.{ }^{\mathrm{TM}} 15\right) / \mathrm{HRT} / \mathrm{CdS} / \mathrm{CdTe}$, with $\mathrm{CdCl}_{2}$ activation, served as the underlying structure for $\mathrm{FeS}_{2}$ film incorporation into $\mathrm{PV}$ devices. These devices were completed by deposition of a metal bilayer of $\mathrm{Cu} / \mathrm{Au}$ to cap the $\mathrm{FeS}_{2}$ interface layer of the back contact. The bilayer consists of $\sim 3 \mathrm{~nm} \mathrm{Cu}$ and $\sim 40 \mathrm{~nm}$ Au thermally evaporated sequentially onto either the $\mathrm{CdCl}_{2}$ activated CdTe layer, in the case of the control cells, or onto the hybrid deposited $\mathrm{FeS}_{2}$ layer for the novel cells. Subsequently, $\mathrm{Cu}$ is diffused by annealing at $150{ }^{\circ} \mathrm{C}$ in dry air for 40 minutes. For the standard back contact deposition used in the fabrication of control cells in this study, all processes were identical with the exception of the $\mathrm{FeS}_{2}$ deposition which was not performed for the control cells.

The $\mathrm{FeS}_{2}$ films were prepared in a hybrid process whereby the Fe was sputtered using a DC magnetron source and the elemental sulfur (S) was evaporated simultaneously using a thermal source. The $\mathrm{FeS}_{2}$ films were deposited over a range of calibrated substrate temperatures from $\sim 165{ }^{\circ} \mathrm{C}$ to $\sim 340{ }^{\circ} \mathrm{C}, 4 \mathrm{mTorr}$ Ar pressure, and $70 \mathrm{~W}$ DC sputtering power. Another important parameter found to control the formation of high quality iron pyrite for use in devices is the sulfur evaporation rate (SER). Several SERs were attempted and high crystalline quality pyrite was obtained when the SER was in the range from $\sim 0.2 \mathrm{~nm} / \mathrm{s}$ to $\sim 0.4 \mathrm{~nm} / \mathrm{s}$, associated with an iron pyrite deposition rate range from $\sim 0.1$ to $0.2 \mathrm{~nm} / \mathrm{s}$ at the Fe sputtering power given above. Depending on the purpose of the $\mathrm{FeS}_{2}$ film, the deposition time was varied from 5 minutes to 1 hour, yielding film thicknesses at these extremes of deposition duration ranging from $\sim 30 \mathrm{~nm}$ to $\sim 750 \mathrm{~nm}$, respectively. When $\mathrm{FeS}_{2}$ films were prepared as an HTL for CdS/CdTe solar cells, film thicknesses of $<100 \mathrm{~nm}$ were preferred. The thicker films were used for materials characterization. Although a complete study of the dependence of device performance on $\mathrm{FeS}_{2}$ film thickness has not been performed, a reduced thickness is beneficial because it reduces (i) the deposition time, (ii) the thickness of $\mathrm{Cu}$ as a component of the $\mathrm{Cu} / \mathrm{Au}$ metal contact, and (iii) the time and temperature required for $\mathrm{Cu}$ diffusion during processing. 
For devices incorporating the $\mathrm{FeS}_{2} \mathrm{HTL}$ and for those serving as controls, the cell areas of $0.085 \mathrm{~cm}^{2}$ were defined by laser scribing. Quantum efficiency (QE) measurements confirmed the measured $\mathrm{J}_{\mathrm{SC}}$ values. Current density vs. voltage measurements were performed in the dark, and under 1 Sun AM1.5G illumination. The crystal structure and purity of $\mathrm{FeS}_{2}$ films were determined by X-ray diffraction (XRD, Rigaku Ultima III X-ray Diffractometer) and Raman spectroscopy (Jobin Yvon Horiba Confocal Raman Spectrometer) measurements, surface morphology was determined using scanning electron microscopy (SEM, Hitachi S-4800), and material stoichiometry was determined by energy dispersive X-ray (EDX) spectroscopy in the same SEM. XRD patterns were analyzed to obtain information on the crystal structure along with the lattice constants at different Miller indices for the samples prepared at different substrate temperatures and also at different SER values. For XRD, SEM, and EDX measurements, $\mathrm{FeS}_{2}$ films were deposited primarily onto soda lime glass substrates, but these measurements were also conducted when the films were deposited onto c-Si substrates.

Absorbance spectra of the films were measured using a spectrophotometer (Perkin Elmer Lambda 1050). Spectroscopic ellipsometry (SE) of the films was performed as well, using a multichannel ellipsometer (J. A. Woollam Co., M2000DI). For these optical characterization techniques, $\mathrm{FeS}_{2}$ thin films were fabricated on soda lime glass and $\mathrm{c}-\mathrm{Si}$ substrates. For determination of the dielectric functions of the films by SE, the $\mathrm{FeS}_{2}$ thin films were deposited on c-Si substrates and were cooled to room temperature before in situ measurement. In situ measurement avoided surface oxidation, and the ellipsometry spectra were corrected for surface roughness layers whose characteristics were determined from real time analysis of the film growth processes. The c-Si substrates were also used to calibrate the substrate temperature in the deposition chamber by applying in situ SE.

\section{RESULTS AND DISCUSSION}

The current density-voltage (J-V) curves are shown in Fig. 1 for the highest efficiency sputtered CdTe devices using novel $\mathrm{FeS}_{2} / \mathrm{Cu} / \mathrm{Au}$ and standard $\mathrm{Cu} / \mathrm{Au}$ back contacts. The solid and dashed lines depict the results of light and dark measurements, respectively. The associated performance parameters shown in Table 1 represent average values from 20 cells for both the $\mathrm{FeS}_{2} / \mathrm{Cu} / \mathrm{Au}$ and the $\mathrm{Cu} / \mathrm{Au}$ back contacts. The metal $\mathrm{Au}$ with its relatively high work function, $\phi \approx 5.0 \mathrm{eV}$, is chosen for the standard back contact to minimize the effect of an opposing diode created by a Schottky barrier at the CdTe/metal interface [15]. From the J-V curves shown in Fig. 1 and the parameter values in Table 1, it can be seen that adding a thin film of $\mathrm{FeS}_{2}$ as an interface layer between CdTe and the metal Au improves the device performance. Whereas $\mathrm{J}_{\mathrm{SC}}$ is similar for both novel and standard back contact types, increases in both $\mathrm{V}_{\mathrm{OC}}$ and FF (in accord with improved series and shunt resistance values) result in increased device efficiency when applying the $\mathrm{FeS}_{2} / \mathrm{Cu} / \mathrm{Au}$ back contact to the sputtered CdTe solar cell. The increase in $\mathrm{V}_{\mathrm{OC}}$ is more than $2 \%$ and the increase in $\mathrm{FF}$ is more than $8 \%$ with the $\mathrm{FeS}_{2} / \mathrm{Cu} / \mathrm{Au}$ back contact as shown in Fig. 1. 
The improvement in device performance observed here for $<100 \mathrm{~nm}$ thick $\mathrm{FeS}_{2}$ HTLs deposited by the hybrid process replicates that observed when using $\sim 1 \mu \mathrm{m}$ thick nanocrystalline $\mathrm{FeS}_{2}\left(\mathrm{FeS}_{2}-\mathrm{NC}\right)$ interface layers [9]. In addition to the significantly different method of $\mathrm{FeS}_{2}$ preparation (hybrid sputtering/co-evaporation used here versus the solution process used previously), the results reported here derive from a different method of $\mathrm{Cu}$ incorporation and diffusion. For the hybrid sputtered/co-evaporated $\mathrm{FeS}_{2}$ thin film, the $\mathrm{FeS}_{2}$ is first deposited onto the activated CdTe surface, and the device is subsequently completed by evaporating $\mathrm{Cu} / \mathrm{Au}$ and annealing the device to diffuse the $\mathrm{Cu}$. In contrast, in the previous study of the solutionprocessed $\mathrm{FeS}_{2}$ back contact layer, $\mathrm{Cu}$ is introduced and diffused into the activated $\mathrm{CdTe}$ prior to deposition of the $\mathrm{FeS}_{2}$-NC layer and evaporation of the Au layer. In this latter case, no thermal processing is used during or subsequent to the $\mathrm{FeS}_{2}-\mathrm{NC}$ or $\mathrm{Au}$ depositions.

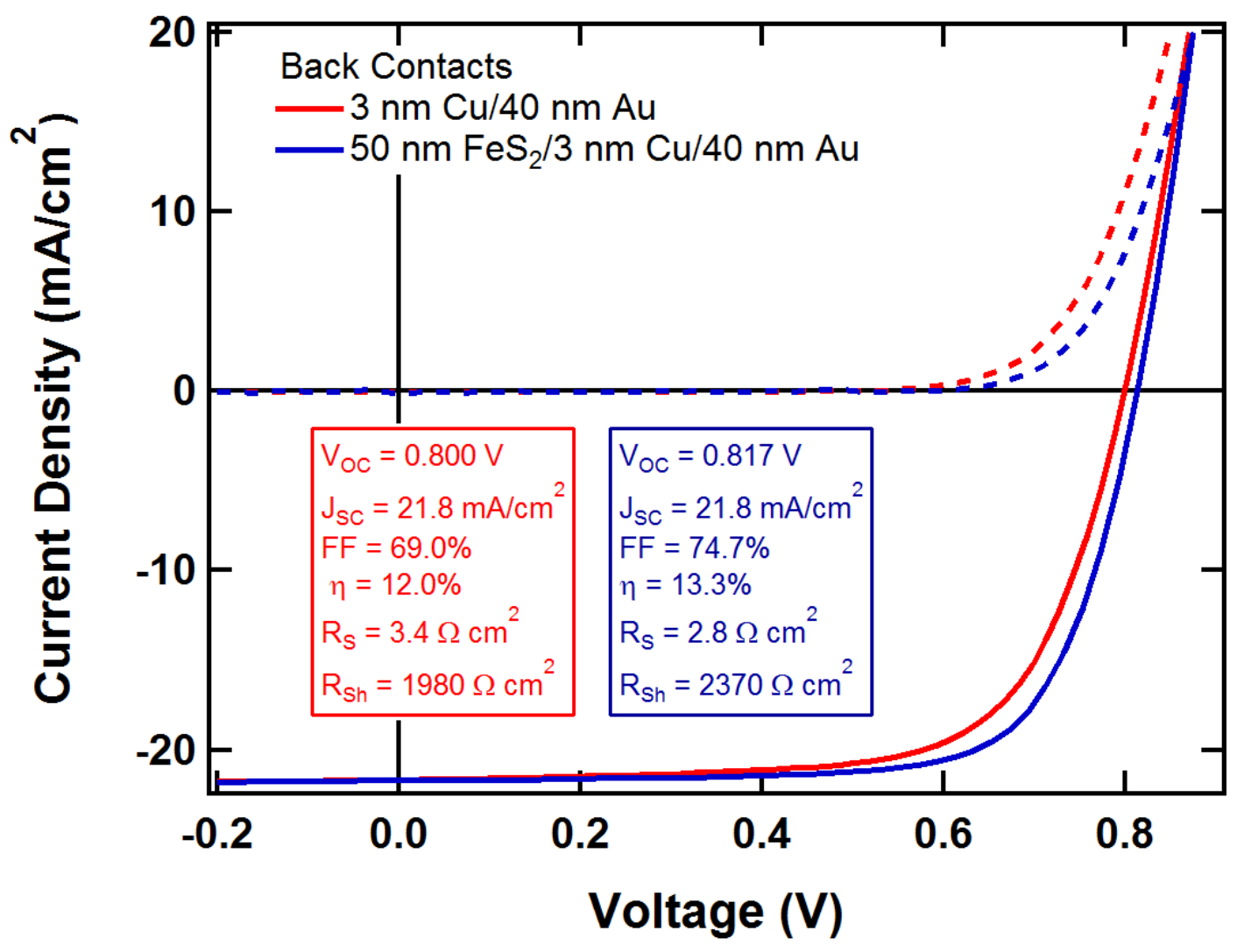

Fig. 1. Current voltage characteristics for the best-performing sputtered CdTe solar cells using standard and novel back contacts as indicated; approximate thicknesses for the components of each of the two back contacts are shown in the graph. $\mathrm{J}_{\mathrm{SC}}$ was verified by external quantum efficiency measurements. 
Table 1. Average parameters and standard deviations of sputter deposited CdTe solar cells having two different back contacts as indicated; the average was taken from the results of 20 cells for each back contact structure. These $\mathrm{J}_{\mathrm{SC}}$ values were as obtained from $\mathrm{J}-\mathrm{V}$ measurements.

\begin{tabular}{|c|c|c|c|c|c|c|}
\hline $\begin{array}{c}\text { Back } \\
\text { Contact }\end{array}$ & $\begin{array}{c}\mathbf{V}_{\mathbf{O C}} \\
(\mathbf{V})\end{array}$ & $\begin{array}{c}\mathbf{J}_{\mathbf{S C}} \\
\left(\mathbf{m A} / \mathbf{c m}^{\mathbf{2}}\right)\end{array}$ & $\begin{array}{c}\mathbf{F F} \\
(\boldsymbol{\%})\end{array}$ & $\begin{array}{c}\boldsymbol{\eta} \\
(\boldsymbol{\%})\end{array}$ & $\begin{array}{c}\mathbf{R}_{\mathbf{S}} \\
\left(\boldsymbol{\Omega} \mathbf{c m}^{\mathbf{2}}\right)\end{array}$ & $\begin{array}{c}\mathbf{R}_{\mathbf{S h}} \\
\left(\mathbf{\Omega}^{\mathbf{2}}\right)\end{array}$ \\
\hline $\mathbf{C u} / \mathbf{A u}$ & $0.79 \pm 0.01$ & $21.7 \pm 0.2$ & $68.4 \pm 0.9$ & $11.8 \pm 0.2$ & $3.7 \pm 0.4$ & $1620 \pm 210$ \\
\hline $\mathbf{F e S}_{2} / \mathbf{C u} / \mathbf{A u}$ & $0.81 \pm 0.01$ & $21.4 \pm 0.3$ & $72.8 \pm 0.9$ & $12.7 \pm 0.3$ & $3.1 \pm 0.3$ & $2580 \pm 560$ \\
\hline
\end{tabular}

In comparison with the $\mathrm{FeS}_{2} \mathrm{NC}$ film, the $\mathrm{FeS}_{2}$ film prepared using the hybrid method is more uniform and compact, and the film is observed to be more strongly adherent to the substrate. Due to the increased density, $\mathrm{FeS}_{2}$ film thicknesses $<100 \mathrm{~nm}$ can be used as interface layers of the back contact for CdTe solar cells. Even with such thin layers, the performances of the cells are as high as those incorporating $\sim 1 \mu \mathrm{m}$ thick $\mathrm{FeS}_{2}-\mathrm{NC}$ films. The $\mathrm{FeS}_{2}$ films deposited by the hybrid method exhibit the same cubic pyrite crystal structure as the $\mathrm{FeS}_{2}-\mathrm{NCs}$, but the film appears slightly less crystalline according to the peak intensities in the XRD pattern of Fig. 2 [10]. The decreased crystallinity may be due to the low substrate temperature for the nucleation and growth $\left(\sim 260{ }^{\circ} \mathrm{C}\right)$ of the $\mathrm{FeS}_{2}$ films. The XRD patterns shown in Fig. 2a were obtained from $\mathrm{FeS}_{2}$ films of $\sim 750 \mathrm{~nm}$ thickness fabricated on soda lime glass substrates with two different sulfur evaporation rates (SERs). At the higher SER, a slight shift in the diffraction peaks to lower $2 \theta$ suggests slight in-plane compressive strain within the iron pyrite grains. The basis for this interpretation is the Poisson effect which indicates that films showing XRD evidence for tensile strain normal to the plane of the film surface are then under compressive strain parallel to the plane of the film [16]. For SER > $0.4 \mathrm{~nm} / \mathrm{s}$, the deposited film was of poor crystallinity and appeared to exhibit a mixture of pyrite, pyrrhotite, and possibly other phases as shown in the Supplementary Material, Fig. S1.

We have investigated films deposited at several substrate temperatures ranging from $\sim 165^{\circ} \mathrm{C}$ to $\sim 340{ }^{\circ} \mathrm{C}$ and found that the pyrite phase can be formed in the range of $\sim 165{ }^{\circ} \mathrm{C}$ to $\sim 260{ }^{\circ} \mathrm{C}$ (Fig. 2b). At the lower substrate temperatures within this range, XRD peak positions are shifted to lower $2 \theta$, corresponding to increased lattice constants and at higher substrate temperature $\left(>260{ }^{\circ} \mathrm{C}\right.$ ) pyrite peaks are missing. For example, the position of the (200) peak shifts monotonically from $33.00^{\circ}$ at $260{ }^{\circ} \mathrm{C}$, to $32.70^{\circ}$ at $212^{\circ} \mathrm{C}$, and to $32.35^{\circ}$ at $165^{\circ} \mathrm{C}$. The average lattice constant of each of the pyrite films $a_{\text {film }}$ has been calculated using different diffraction lines. The results have been compared with the lattice constant of the bulk single crystal $\mathrm{FeS}_{2}$ $a_{b u l k}$, and an estimate by the relation $\varepsilon=\left(a_{f i l m}-a_{b u l k}\right) / a_{b u l k}$ suggests that the in-plane compressive strain $\varepsilon$ is higher at lower substrate temperature according to the argument of the previous paragraph [17]. Because the thermal expansion coefficients for the soda lime glass substrate, $9.0 \times 10^{-6}\left({ }^{\circ} \mathrm{C}\right)^{-1}[18]$, and iron pyrite, $10.4 \times 10^{-6}\left({ }^{\circ} \mathrm{C}\right)^{-1}$ [19] both at $260{ }^{\circ} \mathrm{C}$, are 
relatively close, any contribution to the strain generated by thermal stress upon cooling would be weak and in fact exhibit an opposite trend with decreasing substrate temperature. The larger lattice constant at the lower temperature could be ascribed to lattice strain due to a high density of defects or defect structures that are less stable and form preferentially at the lower substrate temperatures. The average lattice constant as calculated from the various diffraction lines of $\mathrm{FeS}_{2}$ film deposited at $260{ }^{\circ} \mathrm{C}$ was $0.5423 \pm 0.0008 \mathrm{~nm}$ compared with the value of $0.5418 \mathrm{~nm}$ for single crystal pyrite [19-21]. Similarly, average lattice constants of $\mathrm{FeS}_{2}$ films deposited at substrate temperatures of $212{ }^{\circ} \mathrm{C}$ and $165^{\circ} \mathrm{C}$ with SER of $0.275 \mathrm{~nm} / \mathrm{s}$ were $0.5521 \pm 0.0010 \mathrm{~nm}$, and $0.5522 \pm 0.0010 \mathrm{~nm}$, respectively.

A scanning electron microscopy (SEM) image as shown in Fig. 3a demonstrates that the average grain size of the hybrid-deposited polycrystalline $\mathrm{FeS}_{2}$ is smaller than that of the NCs ( $100 \mathrm{~nm}$ edge length) applied in our previous iron pyrite back contact studies. From EDX measurements, the average atomic ratio of $\mathrm{S}$ to $\mathrm{Fe}$ was found to be $2.08 \pm 0.05$ when the substrate temperature was $260{ }^{\circ} \mathrm{C}$. Although we have observed evidence of the formation of $\mathrm{Fe}$ and/or FeS phases upon initiating film growth at a substrate temperature of $260^{\circ} \mathrm{C}$ (according to real time spectroscopic ellipsometry as well as XRD), subsequently we observe the formation of iron pyrite atop the initial layer. At substrate temperatures lower than $260^{\circ} \mathrm{C}$, the $\mathrm{S} / \mathrm{Fe}$ ratio is observed to increase above 2.00 (Fig. 3b). In addition, for these lower substrate temperatures, we observe XRD patterns associated with iron pyrite, but shifted in accordance with an increasing level of in-plane compressive strain. Thus, these results are inconsistent with the concept of a transition from cubic pyrite to the hexagonal troilite (lattice spacings larger than those of iron pyrite) as the substrate temperature is reduced. Evidence for such a cubic to hexagonal transition occurs in this study for the depositions at the high temperatures for which the $\mathrm{S} / \mathrm{Fe}$ ratio has decreased to $\sim 1$ (Fig. 3b). Thus, the FeS phase appearing at substrate temperatures of $312^{\circ} \mathrm{C}$ and $340{ }^{\circ} \mathrm{C}$ is consistent with the conversion of any pyrite phase to troilite.

The electrical characterization of the hybrid-deposited $\mathrm{FeS}_{2}$ was conducted using Hall effect measurements to obtain information on carrier type, free carrier density, and mobility. We found that the polycrystalline $\mathrm{FeS}_{2}$ films are p-type with a net free hole density of $\sim 10^{20} \mathrm{~cm}^{-3}$ and a hole mobility of $\sim 8 \mathrm{~cm}^{2} / \mathrm{Vs}$. The hole mobility value for these $\mathrm{FeS}_{2}$ films is higher than that for $\mathrm{FeS}_{2}$-NC films. We expect that the mobility of holes within each $\mathrm{NC}$, however, is likely to exceed the mobility of holes in the hybrid deposited thin film. This expectation is based on the higher apparent crystallinity of $\mathrm{FeS}_{2} \mathrm{NC}$ films, as indicated by XRD measurement. The observed lower mobility of the NC composite film compared to the hybrid film may then be due to the porosity of the NC film and the presence of organic surfactant molecules. The increased mobility observed in the hybrid-deposited films is expected to yield a reduced contact resistance which would correlate with improved transport of holes from the CdTe to the Au layer, which may in turn improve the open circuit voltage. 

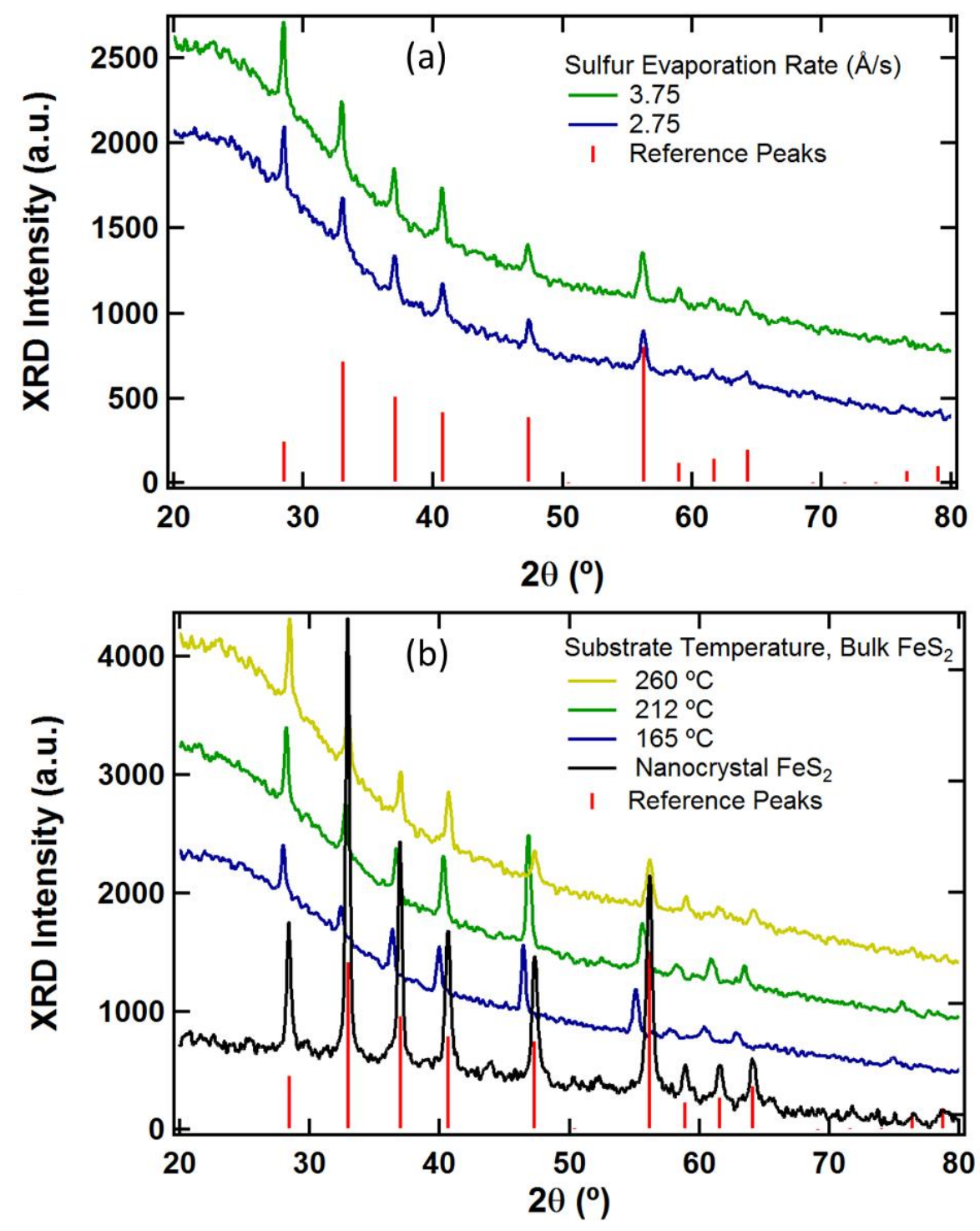

Fig. 2. (a) The X-ray diffraction patterns of polycrystalline $\mathrm{FeS}_{2}$ films deposited on soda-lime glass at 260 ${ }^{\circ} \mathrm{C}$ with SER values of $\sim 0.375 \mathrm{~nm} / \mathrm{s}$ and $\sim 0.275 \mathrm{~nm} / \mathrm{s}$. The extracted lattice constant values in each SER case were similar with an average value of $0.5422 \mathrm{~nm}$. (b) X-ray diffraction scans of $\mathrm{FeS}_{2}$ deposited by hybrid deposition (sputtering of Fe with co-evaporation of $\mathrm{S}$ ) on soda lime glass at substrate temperatures of $260^{\circ} \mathrm{C}, 212{ }^{\circ} \mathrm{C}$ and $165^{\circ} \mathrm{C}$ and a SER of $\sim 0.275 \mathrm{~nm} / \mathrm{s}$. For comparison, an XRD pattern of a FeS $\mathrm{NC}_{2}$ film of similar thickness has been added. The vertical lines represent reference source peaks with PDF \# 97-063-3274. The deposition durations for all samples were 40 minutes.

Optical measurements have also been performed on the hybrid-deposited thin films, including transmittance and reflectance spectroscopy for optical density and absorption coefficient determination over the range from 300 to $2000 \mathrm{~nm}$ (Fig. 3c) and spectroscopic ellipsometry for dielectric function determination over the range from 0.75 to $5 \mathrm{eV}$ (Fig. 3d). From the absorption coefficient of the optimum $\mathrm{FeS}_{2}$ film deposited at $260^{\circ} \mathrm{C}$, the results may suggest significant sub-bandgap optical absorption extending to photon energies below the 
expected bandgap energy of $0.95 \mathrm{eV}$. Another interpretation, supported by real time SE, however, is non-uniformity with depth in the film characterized by a sulphur-poor region at the interface to the substrate. The dielectric functions (Fig. 3d) show features at $1.8 \mathrm{eV}$ and $3.8 \mathrm{eV}$ corresponding to those of the iron pyrite natural crystal; however, the dielectric function amplitudes for the hybrid-deposited film are weaker than that of the natural crystal, but much stronger than that of the thick NC layer as reported by Subedi et al. [11]. Applying the Bruggeman effective medium approximation over the entire spectral range, the thin film exhibits a void content of $21 \mathrm{vol} . \%$ measured relative to the natural crystal which, although considerable, is much lower than that of the NC layer at $62 \mathrm{vol} \%$ as determined by the same method.

Iron pyrite thin films of $\sim 200 \mathrm{~nm}$ to $\sim 500 \mathrm{~nm}$ thickness produced by hybrid deposition have been found to produce no significant photocurrent when used as absorber layers in Schottky and heterojunction solar cells. As shown in Fig. 1, however, improvement in device performance can be observed clearly when using hybrid-deposited $\mathrm{FeS}_{2}$ as an interface layer at the back contact of the CdTe solar cell. We ascribe the performance improvements to a reduced back contact barrier, and to the potential for electron-reflecting behavior at or near the $\mathrm{CdTe} / \mathrm{FeS}_{2}$ interface. The back contact barrier heights $\left(\Phi_{b}\right)$ as calculated from the temperature dependent $\mathrm{J}-\mathrm{V}$ measurement are $0.353 \pm 0.011 \mathrm{eV}$ for standard $\mathrm{Cu} / \mathrm{Au}$ and $0.217 \pm 0.008 \mathrm{eV}$ for the $\mathrm{FeS}_{2} / \mathrm{Cu} / \mathrm{Au}$ back contact. Thus, a $\sim 130 \mathrm{meV}$ reduction in barrier height is observed upon addition of the $\mathrm{FeS}_{2}$ layer, as shown in the Supplementary Material. Even with the reduced barrier to hole transfer when $\mathrm{FeS}_{2}$ is incorporated, $\mathrm{Cu}$ continues to play an important role in maximizing the cell performance. When omitting the $\mathrm{FeS}_{2}$ layer, $3 \mathrm{~nm}$ of $\mathrm{Cu}$ followed by $40 \mathrm{~nm}$ of $\mathrm{Au}$ are evaporated directly onto the activated CdTe surface, and the device is annealed to diffuse $\mathrm{Cu}$ into CdTe to increase the free hole concentration. The increased free hole density at the back of the CdTe layer increases its conductivity, narrows the residual back barrier width, and enhances the tunneling probability for holes through the back barrier into the Au contact layer [22, 23]. Although an increased amount of $\mathrm{Cu}$ may improve the initial back contact performance, excess $\mathrm{Cu}$ is understood to degrade efficiency following thermal cycling over long durations in the field [24]. We find that a $\sim 3 \mathrm{~nm}$ thick evaporated $\mathrm{Cu}$ layer is optimum for a $\sim 2 \mu \mathrm{m}$ thick sputtered CdTe absorber. If we assume that $3 \mathrm{~nm} \mathrm{Cu}$ diffuses uniformly throughout a $2 \mu \mathrm{m} \mathrm{CdTe} \mathrm{layer,} \mathrm{the} \mathrm{number}$ concentration of $\mathrm{Cu}$ atoms is $\sim 1.3 \times 10^{20} \mathrm{~cm}^{-3}$. The $\mathrm{Cu}$ however is not uniformly distributed [25], and due to compensation only a small fraction of the $\mathrm{Cu}$ atoms $(\sim 0.001)$ are ionized to produce free holes [26]. Even with this high average concentration of $\mathrm{Cu}$, however, the back barrier effect is not completely eliminated as shown by temperature dependent $\mathrm{J}-\mathrm{V}$ curves $[27,28]$. 

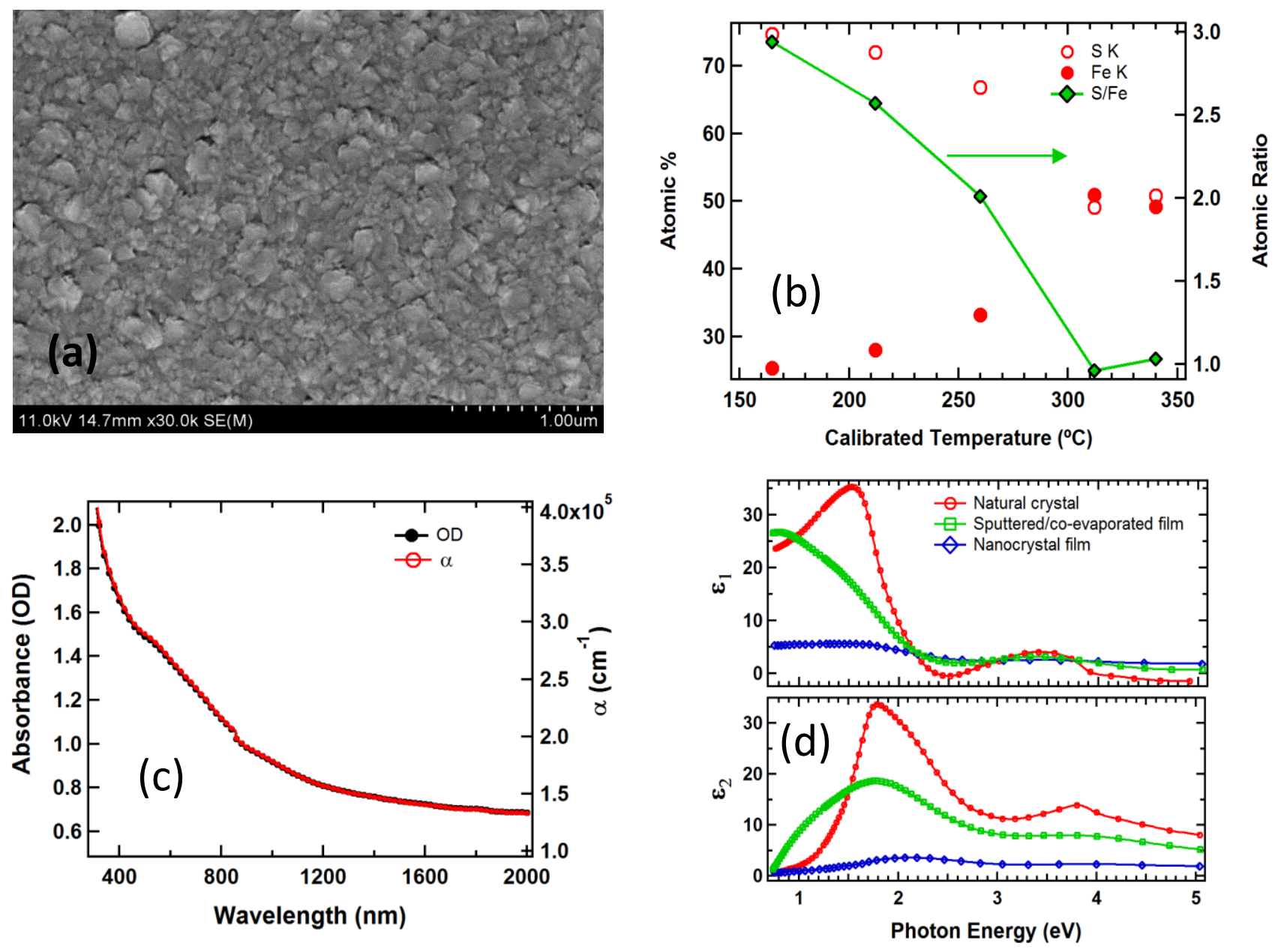

Fig. 3. (a) SEM image of an iron pyrite film deposited by hybrid sputtering/co-evaporation at $260^{\circ} \mathrm{C}$ with a SER of $0.25 \mathrm{~nm} / \mathrm{s}$; (b) EDX data for films deposited by hybrid sputtering/co-evaporation at a SER of $0.25 \mathrm{~nm} / \mathrm{s}$; (c) optical density and absorption coefficient of an iron pyrite thin film fabricated by the hybrid sputtering/co-evaporation method on a soda lime glass substrate; the thickness of the film is $\sim 110$ $\mathrm{nm}$ obtained in a $12 \mathrm{~min}$ deposition. The substrate temperature was $260{ }^{\circ} \mathrm{C}$ and the SER was $\sim 0.25 \mathrm{~nm} / \mathrm{s}$; (d) dielectric functions of three different iron pyrite materials measured at room temperature, including results for a hybrid sputtered/evaporated film of this study obtained in situ (solid lines) in comparison with results for a natural iron pyrite crystal [11] and an $\sim 1.85 \mu \mathrm{m}$ thick layer of iron pyrite nanocrystals [11], the latter two obtained ex situ. The hybrid-deposited thin film was fabricated on a c-Si substrate at a temperature of $260^{\circ} \mathrm{C}$ and a SER of $\sim 0.3 \mathrm{~nm} / \mathrm{s}$. This film exhibited a total bulk layer thickness of $54 \mathrm{~nm}$ and a surface roughness layer thickness of $5 \mathrm{~nm}$. The ellipsometry spectra for the film were corrected for the effects of the surface roughness and underlying film structure in order to extract (by inversion) the dielectric function which was parameterized using an oscillator model.

To reduce the back barrier more effectively, an intermediate semiconductor layer can be deposited before the back contact layers. With suitable band edge energetics, the intermediate semiconductor layer decreases the contact resistance, resulting in improved performance of the CdTe solar cell by promoting hole transport from the CdTe into the back contact metal. 
Fahrenbruch [29] in 1987, and Rioux et al. [30] in 1993, proposed ZnTe as an ohmic back contact for CdTe solar cells, and indeed ZnTe is used at present in some commercial CdTe modules [31]. This semiconductor exhibits a larger bandgap energy than CdTe, a negligible valence band offset relative to CdTe, and a carrier concentration on the order of $10^{18} \mathrm{~cm}^{-3}$ when doped with $\mathrm{Sb}[30,32]$. We find that the $\mathrm{FeS}_{2}$ film plays an apparently analogous role to $\mathrm{ZnTe}$, enhancing both $\mathrm{V}_{\mathrm{OC}}$ and FF. Although not yet experimentally investigated in detail, we propose that the hybrid-deposited polycrystalline $\mathrm{FeS}_{2}$ film forms an ohmic contact to Au and that the $\mathrm{CdTe} / \mathrm{FeS}_{2}$ junction shows a valence band offset favoring efficient transfer of holes. Further studies are planned to investigate and optimize band edge offsets for this system.

The external quantum efficiency (EQE) spectra shown in Fig. 4a indicate that the incorporation of the $\mathrm{FeS}_{2}$ film as a back contact layer in the CdTe solar cell has slightly improved current collection in the long wavelength region of $\lambda>700 \mathrm{~nm}$. Electron-hole pairs generated away from the CdS/CdTe junction, predominantly by these long wavelength photons, benefit from the lower barrier potential present within the $\mathrm{CdTe} / \mathrm{FeS}_{2} / \mathrm{Au}$ contact. Since the $\mathrm{Cu}$ is deposited and diffused after $\mathrm{FeS}_{2}$ layer deposition, the conductivities of both the $\mathrm{FeS}_{2}$ and $\mathrm{CdTe}$ films may have increased as a result. The 5 to $10 \mathrm{~nm}$ blue-shift in the long wavelength $\mathrm{EQE}$ cutoff observed for CdTe devices using the $\mathrm{FeS}_{2}-\mathrm{NC}$ processed back contact [9] has not been observed in this study.

Although the influence of diffusing $\mathrm{Cu}$ on the properties of the iron pyrite layer has yet to be studied, we tested the influence of three different thicknesses of evaporated $\mathrm{Cu}$ on the device performance. In these experiments, we evaporated $3 \mathrm{~nm}, 4 \mathrm{~nm}$, and $5 \mathrm{~nm}$ thick $\mathrm{Cu}$ layers onto the hybrid-deposited $\mathrm{FeS}_{2}$, and devices were then completed in the standard manner including the steps of Au evaporation and annealing. Current density-voltage characteristics are shown in Fig. $4 \mathrm{~b}$ for $\mathrm{CdS} / \mathrm{CdTe}$ devices incorporating the three different thicknesses of $\mathrm{Cu}$ in the $\mathrm{FeS}_{2} / \mathrm{Cu} / \mathrm{Au}$ back contact. In this study we did not observe significant variation in the performance of the devices. Based on these results, we conclude that $\sim 3 \mathrm{~nm} \mathrm{Cu}$ is sufficient to provide the highest performance when the $\mathrm{FeS}_{2}$ thickness is $\sim 50 \mathrm{~nm}$. Application of a thicker $\mathrm{FeS}_{2}$ layer degrades the solar cell performance unless an increased thickness of $\mathrm{Cu}$ is deposited. The presence of elemental $\mathrm{Cu}$ and iron pyrite may potentially yield chalcopyrite formation through a mechanism that could be considered $\mathrm{Cu}$ "gettering" whereby the pyrite serves as a sink for diffusing $\mathrm{Cu}$. Based on the results of Fig. $4 \mathrm{~b}$, the relative insensitivity of device performance with $\mathrm{Cu}$ deposition ( $3 \mathrm{~nm}$ to $5 \mathrm{~nm}$ ) suggests that any gettering mechanism is not playing a key role in determining performance. 

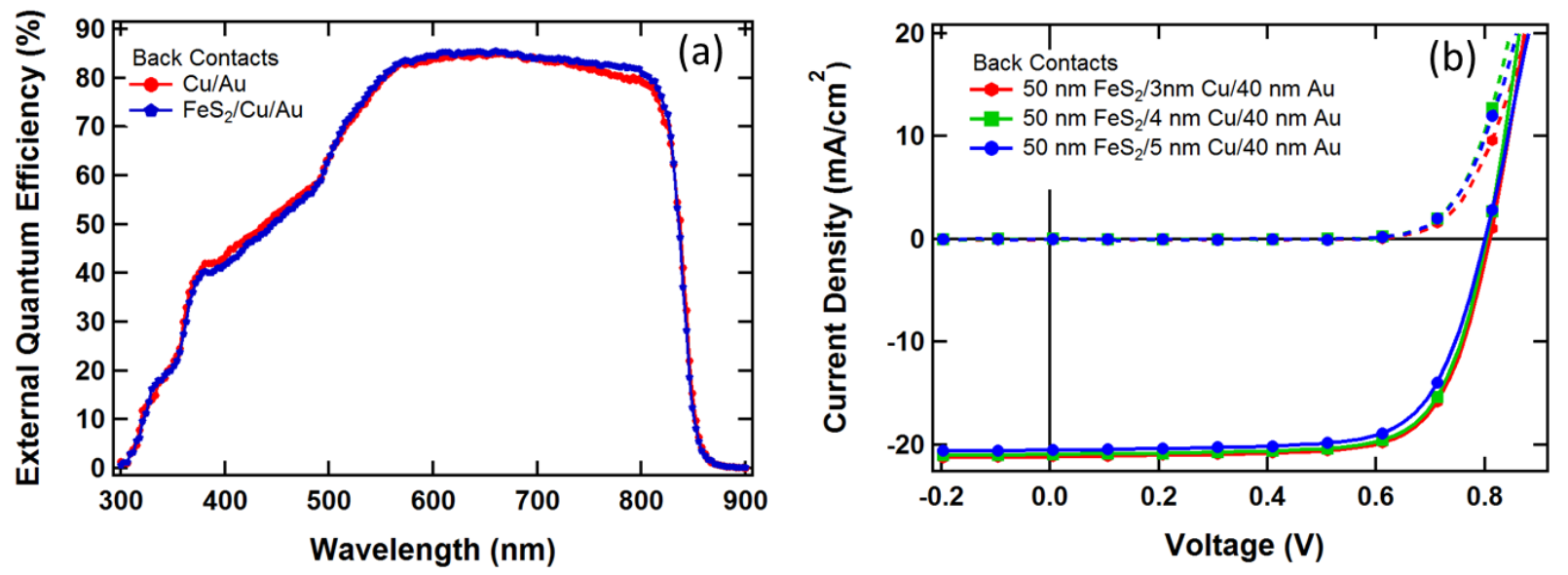

Fig. 4. (a) Typical external quantum efficiency (EQE) of sputter-deposited CdTe devices without and with the $\mathrm{FeS}_{2}$ hole transport layer. The small differences at short wavelength may be attributed to thinner $\mathrm{CdS}$ for the cell with standard $\mathrm{Cu} / \mathrm{Au}$ back contacts. The differences at long wavelengths may be attributed to enhanced electron and hole collection from deeply absorbed photons; (b) J-V behavior for $\mathrm{CdTe}$ solar cells with $\mathrm{FeS}_{2} / \mathrm{Cu} / \mathrm{Au}$ back contacts. The thicknesses of the $\mathrm{FeS}_{2}$ and the Au layers were held constant whereas the $\mathrm{Cu}$ layer thickness was varied as indicated.

Although solar cell parameters such as $\mathrm{V}_{\mathrm{OC}}, \mathrm{J}_{\mathrm{SC}}, \mathrm{FF}, \mathrm{PCE}, \mathrm{R}_{\mathrm{S}}$ and $\mathrm{R}_{\mathrm{Sh}}$ are well accepted indicators of solar cell's performance, additional information can be obtained by analyzing the J$\mathrm{V}$ curves with the help of a general single exponential diode equation given in equation (1).

$J=J_{0} \exp \left[\frac{e}{n k_{B} T}\left(V-R_{S} J\right)\right]+G_{S h} V-J_{L}$,

where $e$ is the electronic charge, $n$ is the diode ideality factor, $k_{B}$ is Boltzmann's constant, $T$ is temperature, $J_{0}$ is the reverse saturation current, $R_{S}$ is the series resistance, $G_{S h}$ is the shunt conductance and $J_{L}$ is the current density at AM1.5G, one sun illumination.

Using the experimental $\mathrm{J}-\mathrm{V}$ curves and diode equation, several important parameters including ideality factor, diode saturation current density, series resistance, and shunt conductance can be calculated and compared. These diode parameters help to understand both qualitative and quantitative information obtained from the J-V curves. Here we experimentally determine these diode parameters to understand the behavior of solar cells by preparing a succession of plots shown in Figs. 5 and 6 for both light and dark measurements. Figs. 5a and 6a show J-V data in the standard form using linear scales for both light and dark measurements. In both cases, current density in forward bias increases more rapidly for devices incorporating $\mathrm{FeS}_{2}$. This indicates that the thin film of $\mathrm{FeS}_{2}$ incorporated into the device helps to lower the series resistance and increase shunt resistance, leading to improved $\mathrm{FF}$ and $\mathrm{V}_{\mathrm{OC}}$ of the devices. 

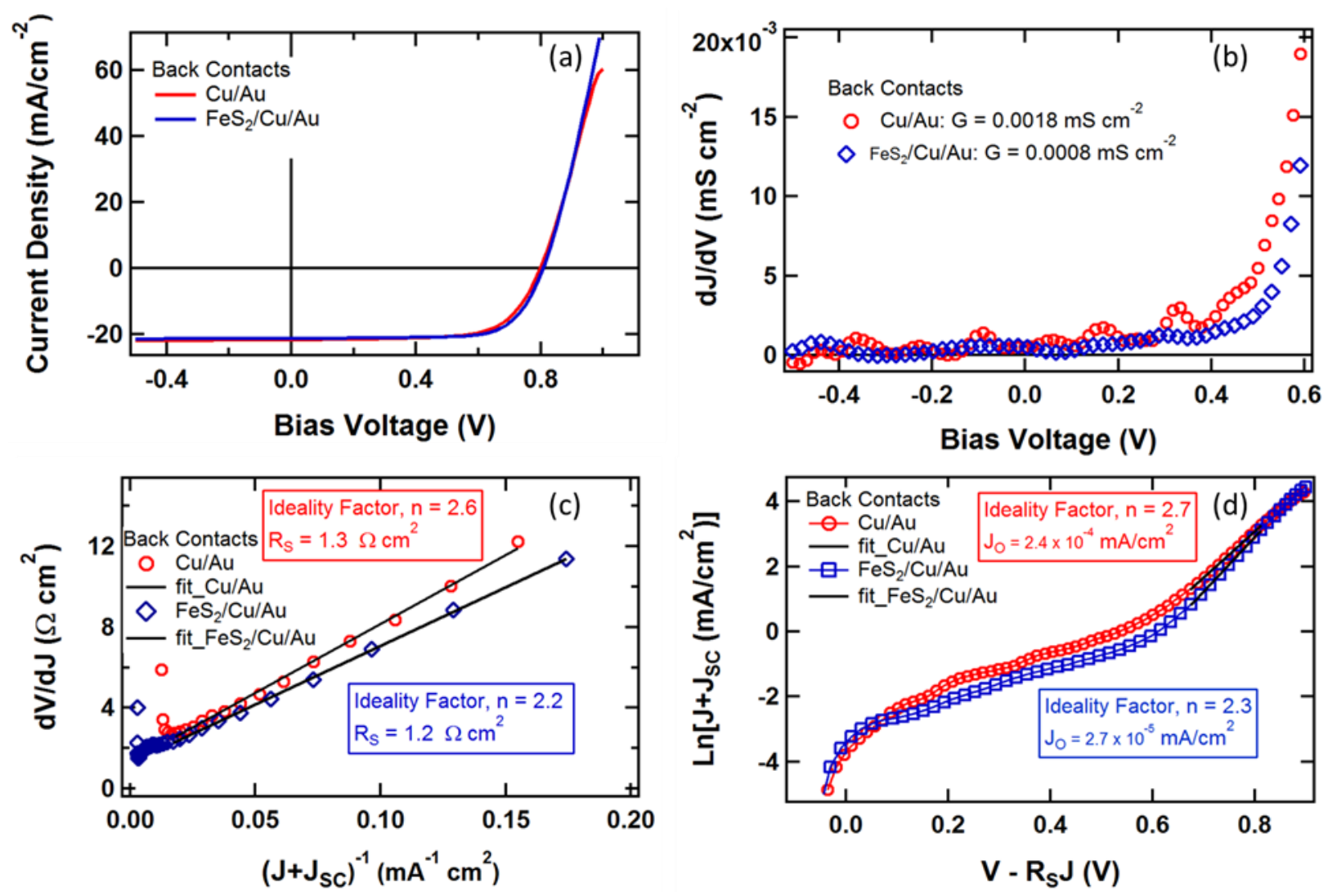

Fig. 5. Analysis of light current density versus voltage characteristics: (a) light J-V curves on a linear scale, (b) shunt characterization, (c) $\mathrm{d} V / \mathrm{d} J$ versus $1 /\left(J+J_{\mathrm{SC}}\right)$ for calculation of $n$ and $R_{S}$, and (d) semi-log scale for calculation of $J_{0}$ and $n$. All panels provide comparisons of sputtered CdTe solar cells incorporating standard $\mathrm{Cu} / \mathrm{Au}$ and novel $\mathrm{FeS}_{2} / \mathrm{Cu} / \mathrm{Au}$ back contacts.

For both back contact types and in both light and dark measurements, $\mathrm{d} J / \mathrm{d} V$ was found to be constant and negligible when plotted as a function of $V$ in reverse bias and in low forward bias regions, as shown in Figs. $5 \mathrm{~b}$ and $6 \mathrm{~b}$. This indicates that shunt resistance of cells with both back contacts are sufficiently high such that the conversion efficiency is not limited measurably. Since $\mathrm{d} J / \mathrm{d} V$ of the $\mathrm{J}-\mathrm{V}$ curve is very small, noise is evident especially for the $\mathrm{Cu} / \mathrm{Au}$ back contact under illumination (Fig. 5b). In the low forward bias region, the first term in the derivative of Eq. (1) is negligible and $\mathrm{d} J / \mathrm{d} V$ then is equal to $G_{S h}$. When the forward bias increases, however, the first term of the derivative increases exponentially. 

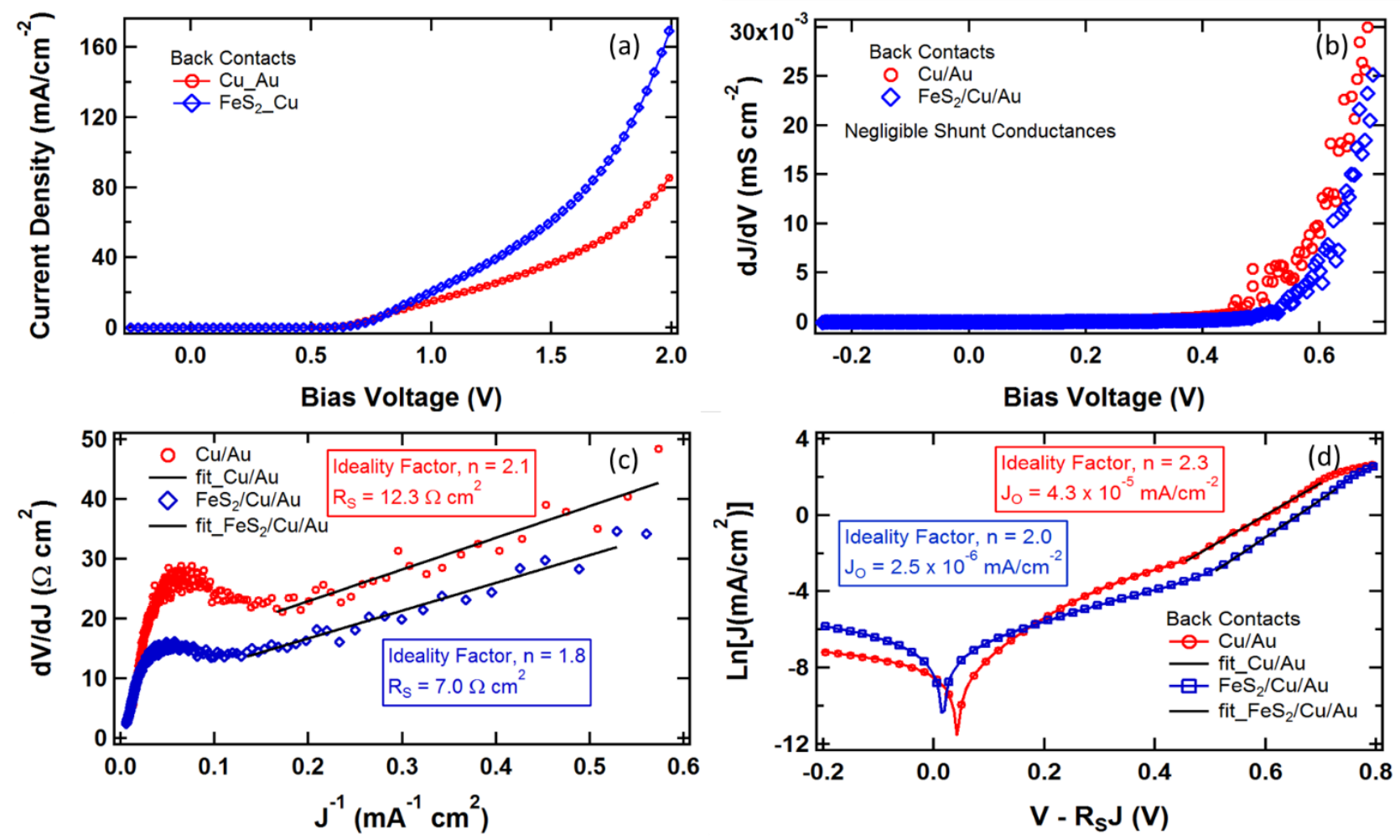

Fig. 6. Analysis of dark current density versus voltage characteristics, including (a) light J-V curves on a linear scale, (b) shunt characterization, (c) $\mathrm{d} V / \mathrm{d} J$ versus $1 / J$ for calculation of $n$ and $R_{S}$, and (d) results on a semi-log scale for calculation of $J_{0}$ and $n$. All panels provide comparisons of sputtered CdTe solar cells incorporating standard $\mathrm{Cu} / \mathrm{Au}$ and novel $\mathrm{FeS}_{2} / \mathrm{Cu} / \mathrm{Au}$ back contacts.

Ideality factors were calculated by plotting the derivative $\mathrm{d} V / \mathrm{d} J$ from the exponential diode equation as a function of the reciprocal of $J+J_{S C}$ when the devices were illuminated and as a function of the reciprocal of $J$ when the devices were not illuminated, as shown in Figs. 5c and 6c. In these cases, the series resistance $R_{S}$ and ideality factors $n$ were obtained from the $y$ intercept and the slope $\left(n k_{B} T / e\right)$ of the diode equation, respectively. The ideality factors calculated using this method for $\mathrm{Cu} / \mathrm{Au}$ and $\mathrm{FeS}_{2} / \mathrm{Cu} / \mathrm{Au}$ back contacts were 2.6 and 2.2 under illumination and 2.1 and 1.8 in the dark, respectively. Slightly higher values of $n$ under illumination are observed because the data are not precisely linear for the $\mathrm{Cu} / \mathrm{Au}$ back contact. The series resistances of the devices with $\mathrm{Cu} / \mathrm{Au}$ and $\mathrm{FeS}_{2} / \mathrm{Cu} / \mathrm{Au}$ back contacts were $1.3 \Omega \mathrm{cm}^{2}$ and $1.2 \Omega \mathrm{cm}^{2}$, respectively, under illumination and $12.3 \Omega \mathrm{cm}^{2}$ and $7.0 \Omega \mathrm{cm}^{2}$ in the dark, respectively. These $n$ and $R_{S}$ values for the device with $\mathrm{Cu} / \mathrm{Au}$ back contacts are similar to values reported elsewhere [33].

Semi-logarithmic graphs of $\ln \left[J+J_{S C}\right]$ versus $V-R_{S} J$ were plotted using the values of $R_{S}$ obtained above for light measurement as shown in Fig. $5 \mathrm{~d}$. Since $J_{\mathrm{SC}}$ is zero in the dark, $\ln [J]$ was plotted versus $V-R_{S} J$ for data collected in the dark. A linear region with at least 1-2 orders of magnitude increase in current density on a log scale is fit using Eq. (1) for the diodes in the light 
and dark to calculate $J_{0}$ and $n$ for cells with $\mathrm{Cu} / \mathrm{Au}$ and $\mathrm{FeS}_{2} / \mathrm{Cu} / \mathrm{Au}$ back contacts. The values of $n$ were 2.7 and 2.3 under illumination and 2.3 and 2.0 in the dark for $\mathrm{Cu} / \mathrm{Au}$ and $\mathrm{FeS}_{2} / \mathrm{Cu} / \mathrm{Au}$ back contacts, respectively. The higher values of $n$ are due to the large deviation in the current for the $\mathrm{Cu} / \mathrm{Au}$ back contact under light and dark conditions. These values are higher than those extracted using the derivatives [comparing Figs. 5c and 6c]. Similarly, the reverse saturation current densities of CdTe solar cells incorporating $\mathrm{Cu} / \mathrm{Au}$ and $\mathrm{FeS}_{2} / \mathrm{Cu} / \mathrm{Au}$ back contacts were found to be $2.4 \times 10^{-4} \mathrm{~mA} / \mathrm{cm}^{2}$ and $2.7 \times 10^{-5} \mathrm{~mA} / \mathrm{cm}^{2}$ under illumination and $4.3 \times 10^{-5} \mathrm{~mA} / \mathrm{cm}^{2}$ and $2.5 \times 10^{-6} \mathrm{~mA} / \mathrm{cm}^{2}$ in the dark, respectively. The $n$ and $J_{0}$ values calculated here for devices with $\mathrm{Cu} / \mathrm{Au}$ and $\mathrm{FeS}_{2} / \mathrm{Cu} / \mathrm{Au}$ back contacts are higher than those determined by Hegedus et al. ( $n$ $=1.7$ and $J_{0}=8 \times 10^{-8} \mathrm{~mA} / \mathrm{cm}^{2}$ ) for dark measurement; however, their values were not presented for light measurement [34]. The solar cell fabrication process described by the authors of reference [34] resembles that used here, with the device structure of glass $/ \mathrm{SnO}_{2} / \mathrm{CdS} / \mathrm{CdTe} / \mathrm{metal}$ and an absorber layer thickness varying over the range of 2-4 $\mu \mathrm{m}$.

Overall, by observing the $\mathrm{J}-\mathrm{V}$ parameters from the light/dark measurements, it can be concluded that the incorporation of $\mathrm{FeS}_{2}$ as an interface layer in the back contact of the $\mathrm{CdS} / \mathrm{CdTe}$ solar cell improves the diode performance parameters. The improvements observed in this study include decreased saturation current density, decreased series resistance and improved ideality factor. The resulting improved diode performance observed in the light/dark leads to increased $V_{O C}$ and $F F$ and overall solar cell performance under illumination.

\section{CONCLUSIONS}

This article reports the demonstration and application of thin film iron pyrite as a hole transport layer at the back contact of $\mathrm{CdS} / \mathrm{CdTe}$ solar cells. Our iron pyrite films are prepared using a hybrid deposition method - which to our knowledge has not been previously reported -- based on sputtering metallic iron while co-evaporating of elemental sulfur. Initial results indicate that devices incorporating a pyrite $\mathrm{FeS}_{2} \mathrm{HTL}$ perform well, showing improvements in $\mathrm{V}_{\mathrm{OC}}$, FF, and $\eta$ as compared with a standard $\mathrm{Cu} / \mathrm{Au}$ contact. Our best cell incorporating the $\mathrm{FeS}_{2} \mathrm{HTL}$ exhibits a fill-factor that exceeds those previously reported for high efficiency solar cells based on RF magnetron sputtered $\mathrm{CdS} / \mathrm{CdTe}$. The $\mathrm{FeS}_{2}$ back contact may ultimately benefit from additional optimization yielding even further increases in CdTe solar cell efficiency. Open-circuit light soak tests are also underway to test the stability of the modified back contact design.

\section{ACKNOWLEDGEMENTS}

KPB and RJE received support from the National Science Foundation's Sustainable Energy Pathways Program under grant CHE-1230246; XT, KPB, PK, and RWC received support from the DOE/NSF F-PACE Program (Contract DE-EE0005405). KPB, RJE, ABP, and MJH were supported by the Air Force Research Laboratory, Space Vehicles Directorate (contract \# FA9453-11-C-0253). In addition, the authors wish to express appreciation to I. Subedi and N. J. 
Podraza for providing the dielectric function of the NC pyrite layer, and to one reviewer who provided especially insightful and helpful comments.

\section{REFERENCES}

[1] C. Wadia, A.P. Alivisatos, D.M. Kammen, Materials availability expands the opportunity for large-scale photovoltaics deployment, Environmental Science \& Technology, 43 (2009) 20722077.

[2] A. Ennaoui, S. Fiechter, C. Pettenkofer, N. Alonso-Vante, K. Büker, M. Bronold, C. Höpfner, H. Tributsch, Iron disulfide for solar energy conversion, Solar Energy Materials and Solar Cells, 29 (1993) 289-370.

[3] P.P. Altermatt, T. Kiesewetter, K. Ellmer, H. Tributsch, Specifying targets of future research in photovoltaic devices containing pyrite $\left(\mathrm{FeS}_{2}\right)$ by numerical modelling, Solar Energy Materials and Solar Cells, 71 (2002) 181-195.

[4] K. Ellmer, C. Höpfner, On the stoichiometry of the semiconductor pyrite $\left(\mathrm{FeS}_{2}\right)$, Philosophical Magazine A, 75 (1997) 1129-1151.

[5] J. Puthussery, S. Seefeld, N. Berry, M. Gibbs, M. Law, Colloidal iron pyrite $\left(\mathrm{FeS}_{2}\right)$ nanocrystal inks for thin-film photovoltaics, Journal of the American Chemical Society, 133 (2010) 716-719.

[6] A. Kirkeminde, R. Scott, S. Ren, All inorganic iron pyrite nano-heterojunction solar cells, Nanoscale, 4 (2012) 7649-7654.

[7] B.J. Richardson, L. Zhu, Q. Yu, Inverted hybrid solar cells based on pyrite $\mathrm{FeS}_{2}$ nanocrystals in P3HT:PCBM with enhanced photocurrent and air-stability, Solar Energy Materials and Solar Cells, 116 (2013) 252-261.

[8] Y.-Y. Lin, D.-Y. Wang, H.-C. Yen, H.-L. Chen, C.-C. Chen, C.-M. Chen, C.-Y. Tang, C.-W. Chen, Extended red light harvesting in a poly (3-hexylthiophene)/iron disulfide nanocrystal hybrid solar cell, Nanotechnology, 20 (2009) 405207.

[9] K.P. Bhandari, P. Koirala, N.R. Paudel, R.R. Khanal, A.B. Phillips, Y. Yan, R.W. Collins, M.J. Heben, R.J. Ellingson, Iron pyrite nanocrystal film serves as a copper-free back contact for polycrystalline CdTe thin film solar cells, Solar Energy Materials and Solar Cells, 140 (2015) 108-114. 
[10] K.P. Bhandari, P.J. Roland, T. Kinner, Y. Cao, H. Choi, S. Jeong, R.J. Ellingson, Analysis and characterization of iron pyrite nanocrystals and nanocrystalline thin films derived from bromide anion synthesis, Journal of Materials Chemistry A, 3 (2015) 6853-6861.

[11] I. Subedi, K.P. Bhandari, R.J. Ellingson, N.J. Podraza, Near infrared to ultraviolet optical properties of single crystal and nanocrystal thin film iron pyrite, Nanotechnology, 27 (2016) 295702.

[12] K.P. Bhandari, P.J. Roland, P. Koirala, R.R. Khanal, N.R. Paudel, R. Collins, Y. Yan, M.J. Heben, R.J. Ellingson, Enhancing the efficiency of CdTe solar cells using a nanocrystalline iron pyrite film as an interface layer, in: Photovoltaic Specialists Conference (PVSC), 2015 42nd IEEE IEEE, 2015, pp. 1-4.

[13] A. Gupta, A.D. Compaan, All-sputtered 14\% CdS/CdTe thin-film solar cell with ZnO:Al transparent conducting oxide, Applied Physics Letters, 85 (2004) 684-686.

[14] P. Koirala, D. Attygalle, P. Aryal, P. Pradhan, J. Chen, S. Marsillac, A.S. Ferlauto, N.J.

Podraza, R.W. Collins, Real time spectroscopic ellipsometry for analysis and control of thin film polycrystalline semiconductor deposition in photovoltaics, Thin Solid Films, 571 (2014) 442446.

[15] G. Stollwerck, J. Sites, Analysis of CdTe back contact barriers, Proceedings of the 13th EU PVSEC, (1995) 2020-2022.

[16] J.A. Thornton, D.W. Hoffman, Stress-related effects in thin films, Thin Solid Films, 171 (1989) 5-31.

[17] S. Singh, R. Srinivasa, S. Major, Effect of substrate temperature on the structure and optical properties of $\mathrm{ZnO}$ thin films deposited by reactive rf magnetron sputtering, Thin Solid Films, 515 (2007) 8718-8722.

[18] W.D. Callister, D.G. Rethwisch, Fundamentals of Materials Science and Engineering: An Integrated Approach, John Wiley \& Sons, 2012.

[19] R. Chrystall, Thermal expansion of iron pyrites, Transactions of the Faraday Society, 61 (1965) 1811-1815.

[20] M. Birkholz, S. Fiechter, A. Hartmann, H. Tributsch, Sulfur deficiency in iron pyrite $\left(\mathrm{FeS}_{2-}\right.$ х) and its consequences for band-structure models, Physical Review B, 43 (1991) 11926-11936. [21] M. Limpinsel, N. Farhi, N. Berry, J. Lindemuth, C.L. Perkins, Q. Lin, M. Law, An inversion layer at the surface of n-type iron pyrite, Energy \& Environmental Science, 7 (2014) 1974-1989. 
[22] S. Demtsu, J. Sites, Effect of back-contact barrier on thin-film CdTe solar cells, Thin Solid Films, 510 (2006) 320-324.

[23] C.R. Corwine, A.O. Pudov, M. Gloeckler, S.H. Demtsu, J.R. Sites, Copper inclusion and migration from the back contact in CdTe solar cells, Solar Energy Materials and Solar Cells, 82 (2004) 481-489.

[24] K.K. Chin, T. Gessert, S.-H. Wei, The roles of $\mathrm{Cu}$ impurity states in CdTe thin film solar cells, in: Photovoltaic Specialists Conference (PVSC), 2010 35th IEEE, IEEE, 2010, pp. 001915-001918.

[25] H.C. Chou, A. Rohatgi, N.M. Jokerst, E.W. Thomas, S. Kamra, Copper migration in CdTe heterojunction solar cells, Journal of Electronic Materials, 25 (1996) 1093-1098.

[26] K.K. Chin, p-Doping limit and donor compensation in CdTe polycrystalline thin film solar cells, Solar Energy Materials and Solar Cells, 94 (2010) 1627-1629.

[27] K.P. Bhandari, R.R. Khanal, N.R. Paudel, P. Koirala, P.J. Roland, T. Kinner, Y. Yan, R.W. Collins, M.J. Heben, R.J. Ellingson, Performance of nanocrystalline iron pyrite as the back contact to CdS/CdTe solar cells, in: Photovoltaic Specialists Conference (PVSC), 40th IEEE, IEEE, 2014, pp. 2293-2298.

[28] J.C. Perrenoud, Low temperature grown CdTe thin film solar cells for the application on flexible substrates, in, Diss., Eidgenössische Technische Hochschule ETH Zürich, Nr. 20460, $2012,2012$.

[29] A.L. Fahrenbruch, Ohmic contacts and doping of CdTe, Solar Cells, 21 (1987) 399-412.

[30] D. Rioux, D.W. Niles, H. Höchst, ZnTe: A potential interlayer to form low resistance back contacts in CdS/CdTe solar cells, Journal of Applied Physics, 73 (1993) 8381-8385.

[31] N. Strevel, L. Trippel, C. Kotarba, I. Khan, Improvements in CdTe module reliability and long-term degradation through advances in construction and device innovation, Photovoltaic international, (2014).

[32] F. Kitagawa, T. Mishima, K. Takahashi, Molecular beam epitaxial growth of ZnTe and ZnSe, Journal of The Electrochemical Society, 127 (1980) 937-943.

[33] S.S. Hegedus, B.E. McCandless, R.W. Birkmire, Analysis of stress-induced degradation in CdS/CdTe solar cells, in: Photovoltaic Specialists Conference (PVSC), 2000 28th IEEE, IEEE, 2000, pp. 535-538. 
[34] S.S. Hegedus, W.N. Shafarman, Thin- film solar cells: device measurements and analysis, Progress in Photovoltaics: Research and Applications, 12 (2004) 155-176. 